\title{
SISTEM PAKAR KERUSAKAN SEPEDA MOTOR MATIC DENGAN METODA HYBRID
}

\author{
Yogi Wiyandra ${ }^{1}$, Firna Yenila ${ }^{2}$, Raja Ayu Mahessya ${ }^{3}$ \\ ${ }^{1}$ Universitas Putra Indonesia YPTK Padang, Indonesia \\ ${ }^{2}$ Universitas Putra Indonesia YPTK Padang, Indonesia \\ ${ }^{3}$ Universitas Putra Indonesia YPTK Padang, Indonesia
}

E-mail: yogiwiyandra@upiyptk.ac.id, firnayenila@upiyptk.ac.id, ayumahessya@upiyptk.ac.id

\begin{abstract}
Abstrak
Kerusakan sepeda motor matic merupakan salah satu masalah yang sering muncul dari pengguna, sehingga tidak jarang dari pengguna langsung membawa kendaraan tersebut ke pakar/teknisi, dimana hal tersebut terkadang memberikan dampak terhadap waktu dan lainnya. Sehingga sistem yang berhubungan dengan komputer sangat dibutuhkan untuk kondisi seperti ini. Penelitian ini bertujuan untuk membantu para pengguna sepeda motor matic dalam mencari solusi terhadap kendaraan yang digunakan sehingga para pengguna paham dengan kendaraan tersebut. Sistem dibangun dengan menggunakan metoda hybrid yang menggabungkan dua metode yakni forward chaining dan certainty factor. Sistem ini bekerja dengan menyadurkan kepakaran teknisi dibidang sepeda motor matic dan beberapa ahli dibidang teknik mesin sehingga bisa memberikan solusi kepada user berupa persentase nilai keyakinan mengenai kondisi sepeda motor matic pada saat konsultasi. Dari hasil konsultasi yang didapatkan bisa digunakan sewaktu-waktu ketika dibutuhkan.
\end{abstract}

Kata kunci: Sepeda Motor, Certainty Factor, Hybrid, Sistem Pakar

\section{Pendahuluan}

Kendaraan bermotor merupakan salah satu transportasi yang diminati oleh masyarakat[10]. Berdasarkan UU No. 14 tahun 1992 yang dimaksud dengan peralatan teknik dapat berupa motor atau peralatan lainnya yang berfungsi untuk mengubah suatu sumber daya energi tertentu menjadi tenaga gerak kendaraan bermotor yang bersangkutan[11]. Pengertian kata berada dalam ketentuan ini adalah terpasang pada tempat sesuai dengan fungsinya [4]. Termasuk dalam pengertian kendaraan bermotor adalah kereta gandengan atau kereta tempelan yang dirangkaikan dengan kendaraan bermotor sebagai penariknya. Sepeda motor matic adalah tipe sepeda motor otomatis yang tidak menggunakan operan gigi manual dan hanya cukup dengan satu akselerasi[5]. 
Cara kerja kopling otomatis yaitu kopling terhubung dan terputus dengan menggunakan gaya centrifugal, yang timbul karena gaya putar poros engkol. Saat kecepatan mesin rendah, kopling secara otomatis terputus, dan pada saat kecepatan mesin meninggi kopling terhubung [3]. Sepeda motor matic paling banyak diminati oleh masyarakat, selain penggunaannya yang mudah harga pun terjangkau [6]. Namun tidak seluruh masyarakat yang menggunakan sepeda motor matic tersebut memahami setiap masalah yang ditimbulkan oleh kendaraan tersebut. Tak jarang di antara para pengguna sepeda motor menerka setiap kerusakan atau permasalahan yang terjadi dengan kendaraan mereka. Sehingga hasil terkaan tersebut berdampak buruk terhadap kendaraan mereka[7]. Sementara untuk berkonsultasi dengan teknisi membutuhkan waktu yang lama. Waktu tersebut juga terkadang berbanding terbalik dengan kesiapan teknisi.

Mengingat hal tersebut maka dibutuhkan sebuah sistem yang memberikan informasi mengenai kondisi sepeda motor matic sebelum di berikan kepada ahlinya untuk di perbaiki. Sistem tersebut memberikan persentase kerusakan sepeda motor matic dengan menggunakan metoda hybrid yang menggabungkan antara forward chaining yang bertujuan untuk mengetahui siklus kerusakan sepeda motor dari awal dan certainty factor memberikan persentase kemungkinan jenis kerusakan yang terjadi.

\section{Tinjauan Literatur}

Sistem pakar adalah memindahkan kepakaran seseorang kedalam sebuah sistem atau aplikasi tertentu dengan harapan akan menghasilkan sebuah informasi sebagaimana yang diinginkan [8]. Mekanisme ini akan menganalisa suatu masalah tertentu dan kemudian mencari jawaban atau kesimpulan yang terbaik. Dari fakta-fakta yang diperoleh selama proses tanya-jawab dengan user, serta aturan-aturan yang tersimpan pada knowledge base, inference engine dapat menarik suatu kesimpulan dan memberikan rekomendasi atau saran yang diharapkan oleh user [12].

\section{a. Forward Chaining}

Forward chaining adalah salah satu metode dari sistem pakar yang mencari atau menelusuri solusi melalui masalah [13]. Dengan kata lain metode ini melakukan pertimbangan dari fakta-fakta yang kemudian berujung pada sebuah kesimpulan yang berdasarkan pada fakta-fakta. Pada metode forward chaining, penjelasan tidak terlalu terlalu terfasilitasi karena subgoals tidak diketahui secara eksplisit sebelum kesimpulannya ditemukan.

b. Certainty Factor

Metode certainty factor digunakan ketika menghadapi suatu masalah yang jawabannya tidak pasti. Ketidakpastian ini bisa merupakan probabilitas[14]. 
Certainty factor menunjukkan ukuran kepastian terhadap suatu fakta atau aturan [10].

$$
\underset{\mathrm{MD}[\mathrm{h}, \mathrm{e}] \ldots(\mathrm{h}, \mathrm{e}]}{\mathrm{C}(1)}=\mathrm{MB}[\mathrm{h}, \mathrm{e}] \quad-
$$

\section{Keterangan :}

$\mathrm{CF}[\mathrm{h}, \mathrm{e}]=$ Faktor kepastian

$\mathrm{MB}[\mathrm{h}, \mathrm{e}]=$ Measure of belief, ukuran kepercayaan atau tingkat keyakinan terhadap hipotesis (h), jika diberikan evidence (e) antara 0 dan 1

$\mathrm{MD}[\mathrm{h}, \mathrm{e}]=$ Measure of disbelief, ukuranketidakpercayaan atau tingkat keyakinan terhadap hipotesis (h), jika diberikan evidence (e) antara 0 dan 1. Adapun beberapa kombinasi certainty factor terhadap premis tertentu:

1. Certainty factor dengan satu premis

$$
\mathrm{CF}[\mathrm{h}, \mathrm{e}]=\mathrm{CF}[\mathrm{e}] * \mathrm{CF}[\text { rule }]=\mathrm{CF}[\text { user }]
$$

* CF[pakar]...(2)

2. Certainty factor dengan lebih dari satu premis

$$
\mathrm{CF}[\mathrm{A} \wedge \mathrm{B}]=\operatorname{Min}(\mathrm{CF}[\mathrm{a}], \mathrm{CF}[\mathrm{b}]) *
$$

$\mathrm{CF}[\mathrm{A} \vee \mathrm{B}]=\operatorname{Max}(\mathrm{CF}[\mathrm{a}], \mathrm{CF}[\mathrm{b}]) *$ $\mathrm{CF}[$ rule] ...(4)

3. Certainty factor dengan kesimpulan yang serupa

$\mathrm{CF}$ gabungan $[\mathrm{CF} 1, \mathrm{CF} 2]=\mathrm{CF} 1+$ $\mathrm{CF} 2 *(1-\mathrm{CF} 1) \ldots(5)$

Kelebihan dari metode ini adalah cocok digunakan pada sistem pakar yang mengukur sesuatu yang pasti atau tidak pasti seperti mendiagnosis penyakit dan perhitungan dari metode ini hanya berlaku untuk sekali hitung, serta hanya dapat mengolah dua data sehingga keakuratannya terjaga[15].

\section{Metodologi}

Penelitian ini dirancang dengan urutan sebagai berikut:

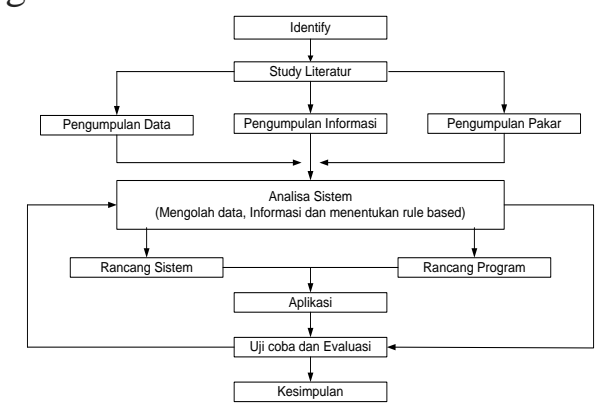

Gambar 1. Kerangka Penelitian

\section{Analisa dan Hasil}

\subsection{Analisa}

Proses analisa dan hasil terhadap deteksi sepeda motor matic ini memiliki beberapa tahapan di antaranya.

Tabel 1. Jenis Kerusakan

\begin{tabular}{ll}
\hline Kode & Kerusakan \\
\hline K001 & ACU \\
\hline K002 & Busi \\
\hline K003 & Celah klep \\
\hline K004 & Injector \\
\hline K005 & Roller \\
\hline K006 & CVT \\
\hline K007 & ECM \\
\hline
\end{tabular}


Tabel 2. Gejala Kerusakan

\begin{tabular}{|c|c|}
\hline Kode & \\
\hline G001 & $\begin{array}{l}\text { Listrik tidak memberikan } \\
\text { signal ketika distater }\end{array}$ \\
\hline G002 & Bunyi klakson tidak ada \\
\hline G003 & Reting tidak berfungsi \\
\hline G004 & $\begin{array}{l}\text { Kondisi listrik kendaraan mati } \\
\text { total }\end{array}$ \\
\hline G005 & Sulit distater manual \\
\hline G006 & Knalpot kendaraan meletup \\
\hline G007 & Tarikan kendaraan terasa berat \\
\hline G008 & $\begin{array}{llll}\text { Muncul asap } & \text { hitam } & \text { dari } \\
\text { knalpot } & & & \\
\end{array}$ \\
\hline G009 & Mesin lebih mudah panas \\
\hline G010 & $\begin{array}{l}\text { Boros penggunaan bahan } \\
\text { bakar }\end{array}$ \\
\hline G011 & Bunyi usik pada mesin \\
\hline G012 & $\begin{array}{l}\text { Suara mesin terdengar } \\
\text { keras/kasar }\end{array}$ \\
\hline G013 & $\begin{array}{l}\text { Kecepatan tempuh kendaraan } \\
\text { tidak optimal }\end{array}$ \\
\hline G014 & $\begin{array}{l}\text { Bunyi kendaraan tidak } \\
\text { nyaman ketika jalan perlahan }\end{array}$ \\
\hline G015 & Kompas kopling lambat \\
\hline G016 & Lari kendaraan tersedak sedak \\
\hline G017 & Kendaraan tiba-tiba mati total \\
\hline G018 & Tidak stabilnya tarikan gas \\
\hline G019 & $\begin{array}{l}\text { Lampu indikator kendaraan } \\
\text { nyala terus }\end{array}$ \\
\hline G020 & Lampu depan sering mati \\
\hline G021 & $\begin{array}{l}\text { Rem motor tidak terlalu } \\
\text { berfungsi }\end{array}$ \\
\hline G022 & $\begin{array}{l}\text { Motor tidak mampu } \\
\text { menempuh ketinggian yang } \\
\text { terbilang normal }\end{array}$ \\
\hline G023 & Oli menetes tiba-tiba \\
\hline
\end{tabular}

\begin{tabular}{ll}
\hline G024 & Motor serasa tidak seimbang \\
\hline G025 & Bohlam lampu sering putus \\
\hline
\end{tabular}

Tabel 3. Kepastian

\begin{tabular}{lll}
\hline Kode & Keterangan & \multicolumn{1}{c}{ Value } \\
\hline KD001 & Tidak & 0 \\
\hline KD002 & Tidak Tahu & 0.2 \\
\hline KD003 & Sedikit Yakin & 0.4 \\
\hline KD005 & Cukup Yakin & 0.6 \\
\hline KD006 & Yakin & 0.8 \\
\hline KD007 & Sangat Yakin & 1
\end{tabular}

Tabel 4. Bobot Pakar

\begin{tabular}{|c|c|c|}
\hline Kode & Gejala & Bobot \\
\hline G001 & $\begin{array}{l}\text { Listrik } \\
\text { memberikan } \\
\text { ketika distater }\end{array}$ & 0.5 \\
\hline G002 & Bunyi klakson tidak ada & 0.4 \\
\hline G003 & Reting tidak berfungsi & 0.8 \\
\hline G004 & $\begin{array}{l}\text { Kondisi listrik } \\
\text { kendaraan mati total }\end{array}$ & 0.7 \\
\hline G005 & Sulit distater manual & 0.4 \\
\hline G006 & $\begin{array}{ll}\text { Knalpot } & \text { kendaraan } \\
\text { meletup } & \end{array}$ & 0.7 \\
\hline G007 & $\begin{array}{l}\text { Tarikan kendaraan terasa } \\
\text { berat }\end{array}$ & 0.8 \\
\hline G008 & $\begin{array}{l}\text { Muncul asap hitam dari } \\
\text { knalpot }\end{array}$ & 0.5 \\
\hline G009 & $\begin{array}{l}\text { Mesin lebih mudah } \\
\text { panas }\end{array}$ & 0.2 \\
\hline G010 & $\begin{array}{l}\text { Boros penggunaan } \\
\text { bahan bakar }\end{array}$ & 0.3 \\
\hline G011 & Bunyi usik pada mesin & 0.4 \\
\hline G012 & $\begin{array}{l}\text { Suara mesin terdengar } \\
\text { keras/kasar }\end{array}$ & 0.4 \\
\hline G013 & $\begin{array}{l}\text { Kecepatan tempuh } \\
\text { kendaraan tidak optimal }\end{array}$ & 0.6 \\
\hline G014 & $\begin{array}{lcl}\text { Bunyi } & \text { kendaraan } & \text { tidak } \\
\text { nyaman } & \text { ketika } & \text { jalan }\end{array}$ & 0.5 \\
\hline
\end{tabular}




\begin{tabular}{lll}
\hline \multicolumn{4}{l}{ perlahan } \\
\hline G015 & Kompas kopling lambat & 0.2 \\
\hline G016 & $\begin{array}{l}\text { Lari kendaran tersedak } \\
\text { sedak }\end{array}$ & 0.5 \\
\hline G017 & $\begin{array}{l}\text { Kendaraan tiba-tiba mati } \\
\text { total }\end{array}$ \\
\hline G018 & $\begin{array}{l}\text { Tidak stabilnya tarikan } \\
\text { gas }\end{array}$ & 0.5 \\
\hline G019 & $\begin{array}{l}\text { Lampu } \\
\text { kendaraan nyala terus }\end{array}$ \\
\hline G020 & $\begin{array}{l}\text { Lampu depan sering } \\
\text { mati }\end{array}$ \\
\hline G021 & $\begin{array}{l}\text { Rem motor tidak terlalu } \\
\text { berfungsi }\end{array}$ \\
\hline G022 & $\begin{array}{l}\text { Motor tidak mampu } \\
\text { menempuh ketinggian }\end{array}$ & 0.7 \\
& yang terbilang normal \\
\hline G023 & Oli menetes tiba-tiba & 0.6 \\
\hline G024 & $\begin{array}{l}\text { Motor serasa tidak } \\
\text { seimbang } 0.1\end{array}$ \\
\hline G025 & $\begin{array}{l}\text { Bohlam lampu sering } \\
\text { putus }\end{array}$ \\
\hline
\end{tabular}

Tabel 5. Tabel Rule

\begin{tabular}{clll}
\hline No & \multicolumn{4}{c}{ Rule } \\
\hline 1 & IF G001 AND G002 & AND \\
& G003 AND G004 & THEN \\
& K001 & & \\
\hline 2 & IF G005 & AND G006 & AND \\
& G007 AND G008 & THEN \\
& K002 & & \\
\hline 3 & IF G007 & AND G009 & AND \\
& G019 AND & G020 & THEN \\
& K003 & & \\
\hline 4 & IF G001 AND G005 & AND \\
& G007 AND G020 & THEN \\
& K004 & & \\
\hline 5 & IF G005 & AND G007 & AND \\
& G011 AND G012 AND G025 \\
& AND G013 THEN K005 \\
\hline
\end{tabular}

\begin{tabular}{clll}
\hline 6 & IF G007 AND G014 AND \\
& G015 AND G012 AND G013 \\
& AND G024 THEN K006 \\
\hline 7 & IF G016 AND G017 AND \\
& G018 AND G023 THEN \\
& K007 & & \\
\hline Dst & & \\
\hline
\end{tabular}

Pembahasan dalam penelitian ini diperlukan untuk mengetahui hasil dari penelitian hingga dapat menyelesaikan permasalahan yang ada pada pengguna kendaraan bermotor matic. Permasalahan yang telah dirumuskan atau diteliti sebelumnya yaitu memastikan metoda hybdrid dapat digunakan untuk menarik kesimpulan pada kasus ini.

Langkah yang digunakan dengan menggunakan metode hybrid (Forward Chaining dan Certainty Factor) dalam memproses gejala-gejala berdasarkan diagnosa kondisi awal menggunakan kaidah dengan premis/gejala tunggal. Contoh poses memperoleh nilai $\mathrm{CF}$ dengan menggunakan tabel rule, nilai bobot pengguna dan nilai bobot pakar:

Tabel 6. Tabel Rule (Aturan)

\begin{tabular}{cll}
\hline No & \multicolumn{2}{c}{ Rule } \\
\hline 1 & IF G001 AND G002 \\
& AND G003 AND G004 \\
& THEN K001 & \\
\hline Dst & & \\
\hline
\end{tabular}

Tabel 7. Nilai Bobot Pengguna

\begin{tabular}{ccc}
\hline Kode & Gejala & $\begin{array}{c}\text { Nilai } \\
\text { Bobot }\end{array}$ \\
\hline
\end{tabular}




\begin{tabular}{llc}
\hline & \multicolumn{1}{c}{ Pengguna } \\
\hline G001 & $\begin{array}{l}\text { Listrik tidak } \\
\text { memberikan } \\
\text { signal ketika } \\
\text { distater }\end{array}$ \\
\hline G002 & $\begin{array}{l}\text { Bunyi klakson } \\
\text { tidak ada }\end{array}$ & 0.8 \\
\hline G003 & $\begin{array}{l}\text { Reting tidak } \\
\text { berfungsi }\end{array}$ & 0.5 \\
\hline G004 & $\begin{array}{l}\text { Kondisi listrik } \\
\text { kendaraan mati } \\
\text { total }\end{array}$ & 0.6 \\
\hline
\end{tabular}

Tabel 8. Nilai Bobot Pakar

\begin{tabular}{llcc}
\hline Kode & \multicolumn{1}{c}{ Gejala } & $\begin{array}{c}\text { Nilai } \\
\text { Bobot } \\
\text { Pakar }\end{array}$ \\
\hline G001 & $\begin{array}{l}\text { Listrik tidak } \\
\text { memberikan } \\
\text { signal ketika }\end{array}$ \\
& $\begin{array}{l}\text { distater } \\
\text { G002 }\end{array}$ & $\begin{array}{l}\text { Bunyi klakson } \\
\text { tidak ada }\end{array}$ \\
\hline G003 & $\begin{array}{l}\text { Reting } \\
\text { berfungsi }\end{array}$ \\
\hline G004 & $\begin{array}{l}\text { Kondisi } \\
\text { kendaraan } \\
\text { total mati }\end{array}$ & 0.4 \\
\hline
\end{tabular}

\begin{tabular}{|c|c|c|c|}
\hline $\mathrm{Cf}$ & $=\mathrm{CF}$ (us & $\mathrm{Cf}$ & $=\mathrm{CF}$ (us \\
\hline ge & er) ${ }^{*} \mathrm{C}$ & ge & er) $* \mathrm{C}$ \\
\hline jal & $\mathrm{F}$ (pak & jal & $\mathrm{F}$ (pak \\
\hline & $=$ ar) & a3 & $=$ ar) \\
\hline & $0.7 * 0$ & & $0.5 * 0$ \\
\hline & 5 & & 8 \\
\hline & 0.35 & $\mathrm{Cf}$ & 0.40 \\
\hline & CF(us & ge & CF(us \\
\hline & er) $* C$ & jal & er) $* C$ \\
\hline & $\mathrm{F}(\mathrm{pak}$ & $\mathrm{a} 4$ & $\mathrm{~F}$ (pak \\
\hline
\end{tabular}

LPPM Universitas Putra Indonesia YPTK Padang

$\begin{array}{ll}\text { ar) } & \text { ar) } \\ 0.8 * 0 . & 0.6^{*} 0 . \\ 4 & 7 \\ 0.32 & 0.42\end{array}$

Dikarenakan terdapat lebih dari satu gejala, maka untuk menentukan CF selanjutnya digunakan persamaan berikut :

CFcombine1(CFgejala1, CFgejala2) $=$ CFgejala1+ CFgejala2*(1- Cfgejala1 $=0.35+0.32 *(1-0.35)$ CFold $1=0.4355$

CFcombine2(CFold1, CFgejala3) = CFold1+CFgejala3 $*$ (1- CFold1) $\mathrm{n}=0$. $4355+0.40 *(1-0.4355)$ CFold $2=0.4758$

Cfcombine3(Cfold2, Cfgejala4) = Cfold2+ Cfgejala4 $*(1-$ Cfold2 $)=0$. $4758+0.42 *(1-0.4758)$ Cfold $3=0.4695$

Certainty factor kombinasi bisa dilakukan sampai pada gejala ke 11 hingga dimunculkan nilai, dari nilai tersebut maka dilakukan aktifitas persentase sebagai contoh sebagai berikut:

$$
\begin{aligned}
& \text { Persentase }=\text { CFpenyakit } * 100= \\
& 0.4695 * 100=46.95 \%
\end{aligned}
$$

Berdasarkan hasil perhitungan, maka keterangan tingkat keyakinan berdasarkan tabel interpretasi dari pakar dan persentase akhir adalah Sedikit Yakin.

\subsection{Hasil}


Berdasarkan analisa terhadap kerusakan sepeda motor matic diatas dapat dihasilkan sebuah sistem sebagai berikut:

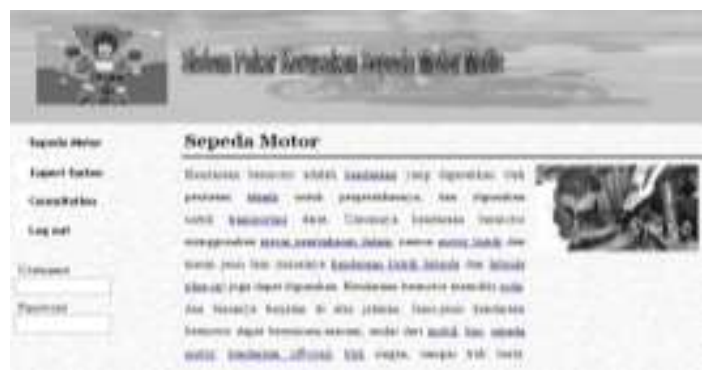

Gambar 2. Form Awal Sistem

Setelah user mengakses tampilan awal tersebut, user akan diarahkan kepada aktivitas konsultasi untuk melakukan penggunaan sistem pakar. User akan diminta untuk menjawab setiap pertanyaan yang diajukan oleh sistem sesuai dengan kondisi user pada saat itu:

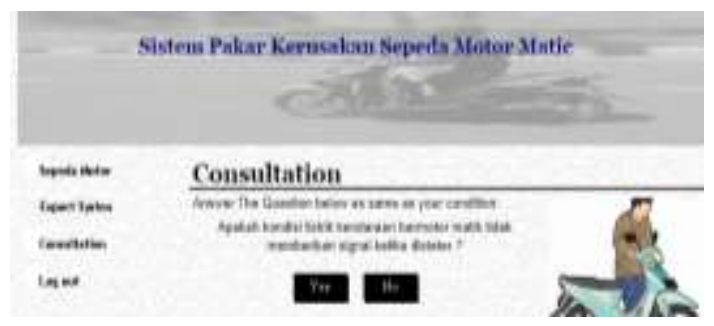

Gambar 3 Konsultasi

Apabila user menjawab "ya" dari pertanyaan tersebut maka sistem akan meminta use memberikan persentase kemungkinan user mengalami kondisi tersebut hingga kemudian konklusi didapatkan. Dan jika user menjawab tidak maka sistem akan menuju ke pertanyaan selanjutnya.

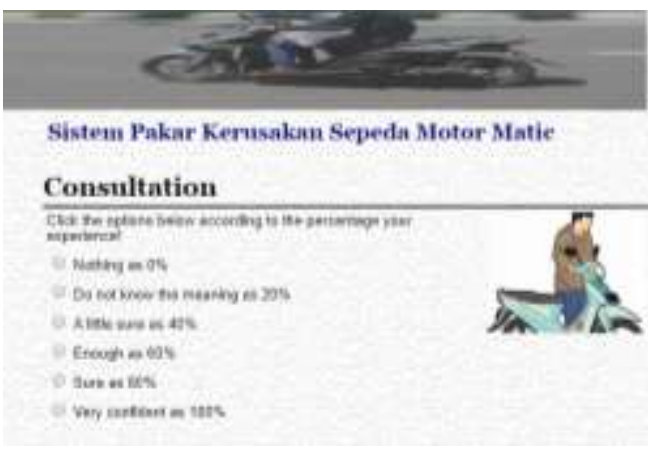

Gambar 4. Persentase keyakinan user

Apabila konsultasi selesai makan sistem akan memberikan keputusan atau kesimpulan berupa sebuah informasi yang bisa dimiliki oleh user dalam bentuk softcopy ataupun hardcopy.

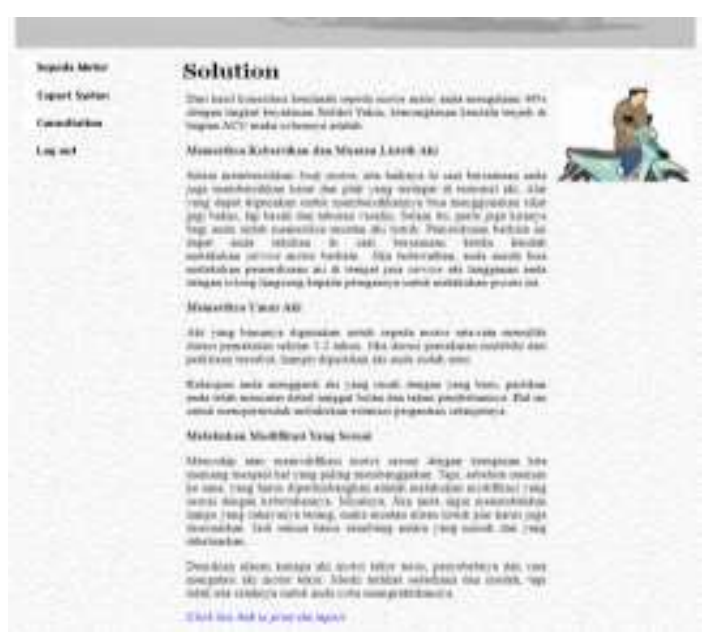

Gambar 5. Kesimpulan

\section{Kesimpulan}

Berdasarkan pembahasan sebelumnya, dapat diambil kesimpulan dari penelitian dan pembuatan sistem pakar kerusakan sepeda motor matic. Dalam upaya membantu pengguna kendaraan bermotor sehingga terhindar dari masalah yang membingungkan tersebut, aplikasi sistem 
pakar ini dapat menjadi alternatif pemecahan masalah, diantaranya;

a. Sistem pakar dibuat agar membantu user untuk mendapatkan informasi tentang kendaraan sepeda motor matic sehingga tidak perlu langsung menghadap teknisi.

b. Metode Hybrid (Forward Chaining dan Certanty Factor) dapat memberikan informasi mengenai kerusakan sepeda motor matic berdasarkan gejala-gejala yang diberikan melalui hasil perhitungan, maka keterangan tingkat keyakinan berdasarkan tabel interpretasi dari pakar berdasarkan konsultasi akhir dalam kasus ini didapatkan persentase akhir sebesar $46 \%$ adalah sedikit yakin.

\section{Referensi}

[1] Putra, A. S., Febriani, O. M., \& Bachry, B. (2018). Implementasi Genetic Fuzzy System Untuk Mengidentifikasi Hasil Curian Kendaraan Bermotor Di Polda Lampung. SIMADA (Jurnal Sistem Informasi dan Manajemen Basis Data), 1(1), 21-30.

[2] Karina, N., \& Budiarso, N. (2016). Analisis Efektivitas dan Kontribusi Pajak Kendaraan Bermotor terhadap Pendapatan Asli Daerah Provinsi Gorontalo. Jurnal EMBA: Jurnal Riset Ekonomi, Manajemen, Bisnis dan Akuntansi, 4(1).
[3] Amin, M., \& Subri, M. (2016). Uji Performa Filter Gas Emisi Kendaraan Bermotor Berbasis Keramik Porous Dengan Aditif Tembaga, Tio2 Dan Karbon Aktif Dalam Penurunan Kadar Gas Carbon Monoksida. Mekanika, 15(2).

[4] Gusnita, C. (2016). Polusi Udara Kendaraan Bermotor sebagai Bentuk Kejahatan Tanpa Korban. SISI LAIN REALITA, 1(2), 47-58.

[5] Putri, D. C. (2016). PENGAPLIKASIAN SENSOR RFID SEBAGAI KUNCI KONTAK OTOMATIS PADA KENDARAAN BERMOTOR RODA DUA BERBASIS ARDUINO UNO (Doctoral dissertation, Politeknik Negeri Padang).

[6] Irawan, A., \& Tyagita, D. A. (2016). Inovasi Peningkatan Efisiensi Konsumsi Bahan Bakar Motor bensin Dengan Penambahan Tabung Induksi (Studi Kasus Sepeda Motor Matic 113cc). Jurnal Ilmiah Inovasi, 16(2).

[7] Fajar, A. (2016). Sistem Pakar Diagnosis Kerusakan kendaraan Menggunakan Teori Probalitas Bayesian (Studi Kasus di SMK Negeri 1 Talaga) (Doctoral dissertation, Universitas Komputer Indonesia). 
[8] Kurniawan, D. E., \& Surur, M. N. (2016). perancangan sistem pengamanan sepeda motor menggunakan mikrokontroler raspberry $\mathrm{Pi}$ dan smartphone android. Jurnal Komputer Terapan, 2(2), 93-104.

[9] Yenila, F., \& Wiyandra, Y. (2018). EXPERT SYSTEM PELANGGARAN

KENDARAAN BERMOTOR DI INDONESIA DENGAN METODA FORWARD CHAINING. TEKNOLOGI, 6(2).

[10] Susilawati, K. E., \& Budiartha, K. (2013). Pengaruh kesadaran wajib pajak, pengetahuan pajak, sanksi perpajakan dan akuntabilitas pelayanan publik pada kepatuhan wajib pajak kendaraan bermotor. E-Jurnal Akuntansi, 345-357.

[11] Indonesia, R., \& INDONESIA, P. R. (2009). UNDANGUNDANG TENTANG LALU LINTAS DAN ANGKUTAN J ALAN (No. 22). UU.

[12] Kuswoyo, D., Agani, N., \& Luhur, U. B. (2015). Model Perhitungan Kebutuhan Bandwidth Jaringan Komputer menggunakan Sistem Pakar Fuzzy dengan Metode Adaptive Neuro Fuzzy Inference System (ANFIS): Studi Kasus PT. GMF Aero Asia Cengkareng. Jurnal TICom, 3(3).

[13] Abu-Nasser, B. S., \& AbuNaser, S. S. (2018). Cognitive System for Helping Farmers in Diagnosing Watermelon Diseases. International Journal of Academic Information Systems Research (IJAISR), 2(7), 1-7.

[14] Chen, W., Pourghasemi, H. R., \& Naghibi, S. A. (2018). A comparative study of landslide susceptibility maps produced using support vector machine with different kernel functions and entropy data mining models in China. Bulletin of Engineering Geology and the Environment, 77(2), 647-664.

[15] Achmadi, S., Mahmudi, A., \& Gita, A. N. (2018). Expert System Design to Diagnos of Virus Infection Disease in Children with Certainty Factor Method. JOURNAL OF SCIENCE AND APPLIED ENGINEERING, 1(2) 